Louisiana State University

LSU Digital Commons

Faculty Publications

Department of Oceanography \& Coastal

Sciences

3-1979

\title{
Land Loss in Coastal Louisiana (U.S.A.)
}

N. J. Craig

R. Eugene Turner

euturne@Isu.edu

J. W. Day Jr.

Follow this and additional works at: https://digitalcommons.Isu.edu/oceanography_coastal_pubs

\section{Recommended Citation}

Craig, N. J., Turner, R., \& Day, J. W. (1979). Land Loss in Coastal Louisiana (U.S.A.). Environmental

Management, 3 (2), 133-144. Retrieved from https://digitalcommons.Isu.edu/

oceanography_coastal_pubs/166

This Article is brought to you for free and open access by the Department of Oceanography \& Coastal Sciences at LSU Digital Commons. It has been accepted for inclusion in Faculty Publications by an authorized administrator of LSU Digital Commons. For more information, please contact ir@lsu.edu. 


\section{Land Loss in Coastal Louisiana (U.S.A.)}

\author{
N. J. CRAIG, R. E. TURNER, and J. W. DAY JR. \\ Center for Wetland Resources \\ Louisiana State University \\ Baton Rouge, Louisiana, U.S.A. 70803
}

ABSTRACT / This paper examines causes and consequences of wetland losses in coastal Louisiana. Land loss is a cumulative impact, the result of many impacts both natural and artificial. Natural losses are caused by subsidence, decay of abandoned river deltas, waves, and storms. Artificial lósses result from flood-control practices, impoundments, and dredging and subsequent erosion of artificial channels. Wetland loss also results from spoil disposal upon wetlands and land reclamation projects.

Total land loss in Louisiana's coastal zone is at least 4,300 ha/ year. Some wetlands are converted to spoil banks and other ecosystems so that wetland losses are probably two to three times higher. Annual wetland losses in the Barataria Bay basin are $2.6 \%$ of the wetland area. Human activities are the principal determinants of land loss. The present total wetland area directly lost because of canals may be close to $10 \%$ if spoil area is included. The interrelationship between hydrology, land, vegetation, substrate, subsidence, and sediment supply are complicated; however, hydrologic units with high canal density are generally associated with higher rates of land loss and the rate may be accelerating.

Some cumulative impacts of land loss are increased saltwater intrusion, loss of capacity to buffer the impact of storms, and large additions of nutrients. One measure of the impact is that roughly $\$ 8-17 \times 10^{6}($ U.S.A.) of fisheries products and services are lost annually in Louisiana.

Viewed at the level of the hydrologic uniț, land loss transcends differences in local vegetation, substrate, geology, and hydrology. Land management should therefore focus at that level of organization. Proper guideline recommendations require an appreciation of the long-term interrelations of the wetland estuarine system.

\section{Introduction}

Man-made modifications in Louisiana wetlands, which are changing the conditions of existence from its very foundations, are the result of flood protection, deforestation, deepening channess, and the cutting of navigation and drainage canals. . . Reclamation and flood control as practiced in Louisiana have been more or less a failure, destroying valuable resource efits originally desired. Reclamation experts and real estate promoters have been killing the goose that laid the golden egg ... our future conservation policy should be a restoration of those natural conditions best suited to an abundant marsh, swamp, and aquatic fauna, but under some degree of control at all times, to the end that the state and nation may enjoy a more balanced diet, healthful recreation, and enduring prosperity. (Viosca 1928)

There is often a choice in environmental management between a "prudence option" to maintain land as it is and a "progress option" to use it (e.g., Cook 1978). The choice of the progress option has often prevailed over the conservation option since the two options are often seen as mutually obtainable management choices (as exemplified in the multiple-use concept of land management). This is true

KEY WORDS: Coastal zone Management, Fisheries, Marshes, Wetlands, Louisiana without producing the permanent compensating ben-

of the Louisiana coastal zone. The grand scale of the area is impressive. Louisiana has $30 \%$ of the nation's coastal wetlands (Turner and Gosselink 1975) at the mouth of the largest river in North America (which drains $40 \%$ of the United States) and produces vast quantities of fish as well as oil and gas. Approximately $50 \%$ of the United States Corps of Engineers permits for dredging are for this area. The Mississippi River passes through a well-developed industrial corridor before debouching into the Gulf of Mexico. This intense use of the area has required and continues to require many decisions about its management. Some of these decisions are made locally; others were made 50 years ago by the national government. A review of land loss in coastal Louisiana is useful to highlight the influence of human decisions on our use of the environment. This paper documents the couplings within and between ecosystems in Louisiana specifically, but it also serves as a general example of the framework land managers might more seriously consider in managing the coastal zone. Wetland loss rates throughout the United States are generally in proportion to population density and industrial development (Gosselink and Baumann 1978), so the problems we discuss here are widespread.

Land loss in Louisiana's coastal zone is a problem with broad management ramifications. The cumulative impacts we discuss include (1) hydrologic change which brings increased saltwater intrusion and/or eutrophication; (2) losses in storm buffer capacity; (3) a decrease in waste as0364-152X/79/0003-0133\$02.40 (c) 1979 Springer-Verlag New York Inc. 


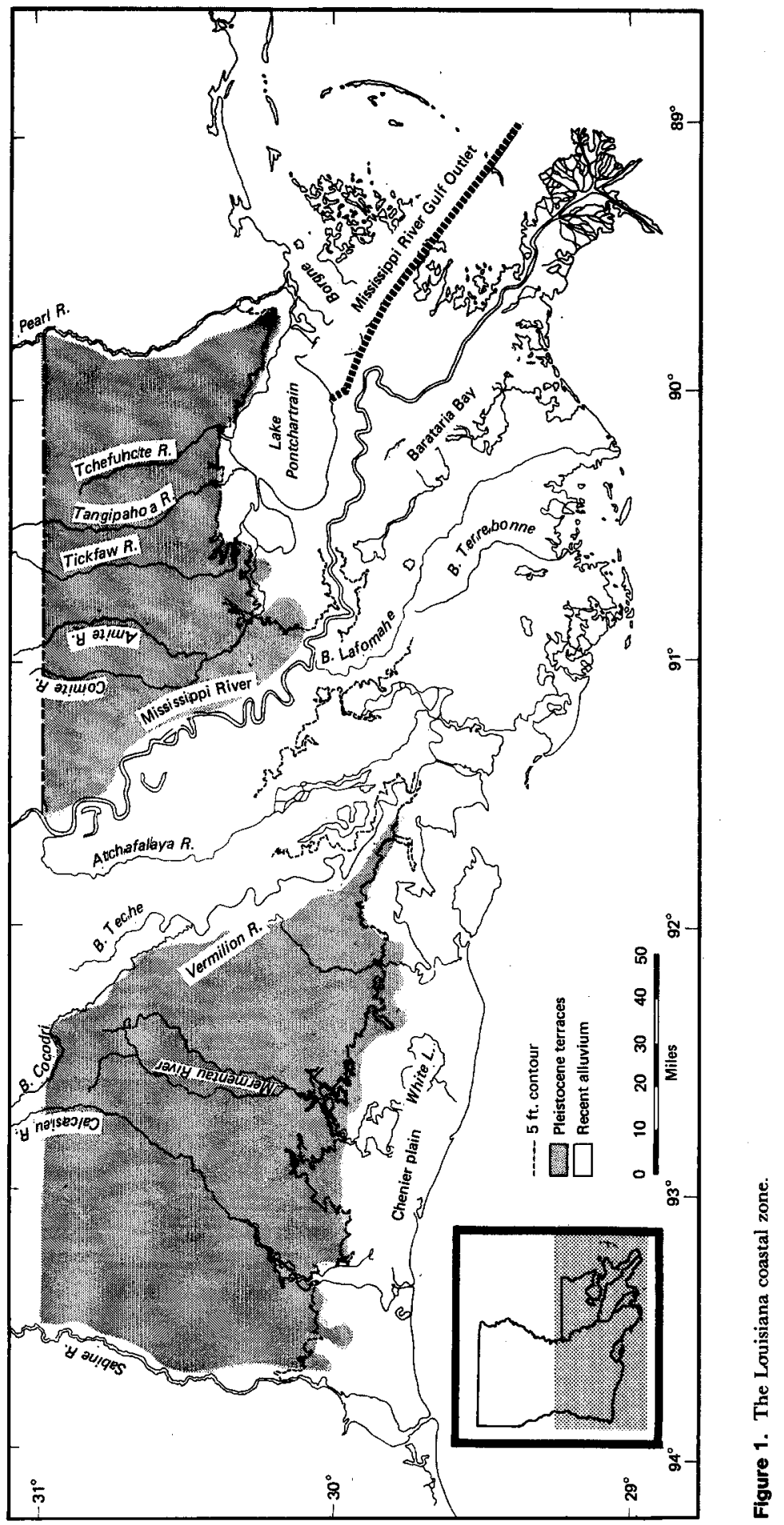


similation capacity of wetlands; and (4) diminished nursery area for Louisiana's coastal finfish and shellfish resources. Land loss is the consequence of many interacting factors, including flood control, navigation improvement, impoundments, and canalization, as well as natural biologic and geologic processes.

Coastal Louisiana (Fig. 1) is a result of sedimentation by the Mississippi River over the past 7,000 years, largely since the last rise in sea level. Frequent channel changes by the Mississippi River have created broad areas of near-sea-level wetlands (Frazier 1967). In an active delta, sedimentation exceeds erosion and there is a net land gain. In an abandoned delta the reverse holds true. Previously, land loss in old Mississippi River deltas was compensated for by land building in the active delta. This is no longer so. The extensive man-made levee system along the Mississippi has virtually eliminated overbank flooding and most sedimentation is in deep continental slope waters. The Atchafalaya River is creating a new delta, but not as fast as land is lost throughout the coastal zone.

The lost coastal land is generally wetlands (marsh and swamp). Losses occur in three basic ways: (1) Wetlands become open water because of natural or artificial processes; loss of this type may be caused by erosion, subsidence, or dredging to form canals, harbors, etc. (2) Wetlands are covered by fill material and altered to terrestial habitat. Placement of spoil from dredging is the most common example. (3) Wetlands can be wholly or partly isolated by spoil banks. Some impounded areas are permanently flooded to enhance waterfowl habitat and/or maintain freshwater conditions. Examples of this type of impoundment are on the Sabine and Lacassine National Wildlife Refuges. Some diked areas are drained for agricultural or urban purposes. Most of metropolitan New Orleans is located in drained wetlands.

In this paper we define land loss as the substantial removal of land from its ecologic role under natural conditions. This definition includes the above three types of wet land alteration. A hydrologic unit or basin is defined as the "natural watershed" in which an estuarine bay is found. In Louisiana there are seven quite different hydrologic units.

Our objectives in this study are (1) to review the existing information and make a qualitative and quantitative documentation of land loss in coastal Louisiana; (2) to determine the relative importance of various processes in causing land loss; (3) to investigate the cumulative impacts of land loss; and (4) to present management guidelines, recommendations, and suggestions for further research.

\section{Documentation of Land Loss}

Several inventories have been made of water bodies (including canals and impoundments) in Louisiana's coastal zone (Adams and others 1976, Barrett 1970, Chabreck 1972, Gagliano and van Beek 1970a). The methods and results of these surveys are compared in Table 1. These studies indicate that the use of photomosaics most accurately delineates the density of canals and total marsh areas in the Barataria hydrologic unit. The accuracy of this technique lies in the fact that it gives complete coverage over a short

Table 1 Summary of inventory results of land

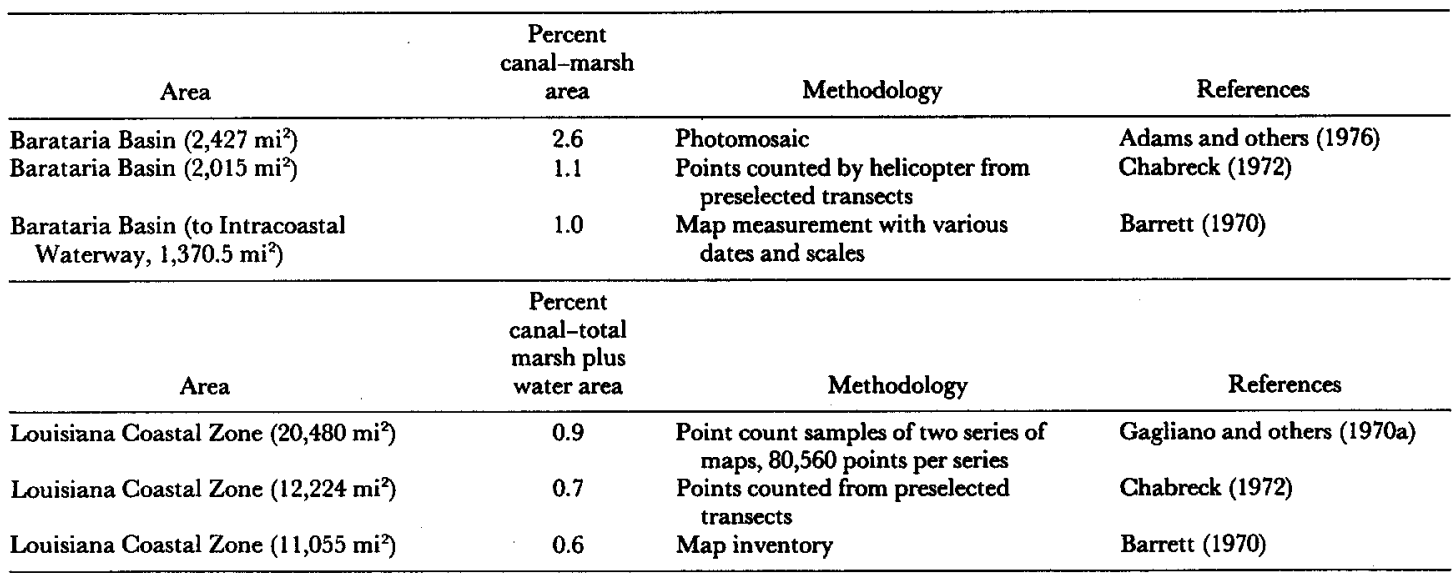


Table 2 Land loss (ha/year) per vegetative type and percent of total land loss in the management units of Louisiana coastal zone (1890-1960)

\begin{tabular}{ccccc}
\hline $\begin{array}{c}\text { Management } \\
\text { unit }\end{array}$ & $\begin{array}{c}\text { Saline } \\
\text { marsh }\end{array}$ & $\begin{array}{c}\text { Brackish } \\
\text { marsh }\end{array}$ & $\begin{array}{c}\text { Fresh } \\
\text { marsh }\end{array}$ & $\begin{array}{c}\text { Swamp } \\
\text { forest }\end{array}$ \\
\hline Pontchartrain- & 164 & 436 & 3 & 73 \\
St. Bernard & $24 \%$ & $64 \%$ & $1 \%$ & $11 \%$ \\
Mississippi & 1.5 & 95.4 & 118 & - \\
$\quad$ River & $1 \%$ & $37 \%$ & $62 \%$ & \\
Barataria & 337 & 371 & 77 & 59 \\
$\quad$ Basin & $40 \%$ & $44 \%$ & $9 \%$ & $7 \%$ \\
Terrebonne & 182 & 187 & 169 & 69 \\
$\quad$ Basin & $30 \%$ & $31 \%$ & $28 \%$ & $11 \%$ \\
Atchafalaya & 0.7 & 4 & 43 & 7 \\
River & $1 \%$ & $9 \%$ & $78 \%$ & $12 \%$ \\
Vermilion & 5.3 & 163 & 11 & 15 \\
Basin & $3 \%$ & $84 \%$ & $6 \%$ & $7 \%$ \\
Chenier & 11.5 & 107 & 77 & - \\
Plain & $6 \%$ & $55 \%$ & $39 \%$ & \\
Total & 701 & 1366 & 499 & 223 \\
& $25 \%$ & $49 \%$ & $18 \%$ & $8 \%$ \\
\hline
\end{tabular}

${ }^{\text {a }}$ Does not include the current delta building in Atchafalaya Bay.

time period and is a direct picture of an area. By contrast, present quadrangle map dates may vary as much as 20 years. The use of the photomosaics is preferred over the use of maps, especially older maps of the 1930s, when surveying techniques were not accurate and in which canals and other features appear to be stylized.

The studies by Gagliano and van Beek (1970) and Adams and others (1976) are of particular interest because in both of these studies an attempt has been made to determine rates of land loss. Gagliano and van Beek reported a net annual land loss in the coastal zone of 4,346 ha $(16.5$ $\mathrm{mi}^{2}$ ). We superimposed Gagliano's and van Beek's (1970) map of land change in the coastal zone over Chabreck's and others' (1968) map of vegetative types. This composite map was digitized to determine percent annual land loss per vegetative type for the seven management units of the Louisiana coastal zone. The results (Table 2) indicate that

Table 3 Land loss in Barataria Bay

\begin{tabular}{lcc}
\hline & $\begin{array}{c}\text { Gagliano and } \\
\text { van Beek (1970) } \\
1890-1960 \\
\text { (ha/year) }\end{array}$ & $\begin{array}{c}\text { Adams and } \\
\text { others }(1976) \\
1960-1974 \\
\text { (ha/year) }\end{array}$ \\
\hline Salt marsh & 337 & $394-842$ \\
Brackish marsh & 372 & $535-1593$ \\
Fresh marsh & 77 & $366-566$ \\
\multicolumn{1}{c}{ Total marsh } & $\mathbf{7 8 6}$ & $1295-3001$ \\
\hline
\end{tabular}

the brackish marsh is deteriorating at a higher net rate than any other wetland type. The total rate of land loss for brackish marsh across the state is $1,366 \mathrm{ha} /$ year, $701 \mathrm{ha} /$ year for saline marsh, $499 \mathrm{ha} /$ year for fresh marsh, and 223 ha/year for swamp forest.

Within the entire coastal zone, canals alone are equal to $1.4 \%$ of the present marsh area. Seventy-four percent of land loss is occurring in the brackish and saline marshes. Data for the Barataria hydrologic unit allow a comparison of land loss over different time intervals (Table 3). The data from Gagliano and van Beek (1970), using the pointcounted technique, are for 1890-1960. The digitized data of Adams and others (1976) are for 1960-1970 and 19701974.

The rate of land loss determined by Adams and others is significantly higher than that calculated from Gagliano and van Beek. Tests comparing digitizing and point counting for the same area yielded similar findings (Adams and others 1976). It is not likely, therefore, that a difference in the methods can account for the large differences in estimates of land loss rate. It seems that the rate of land loss in the Barataria hydrologic unit is accelerating.

\section{Causes of Land Loss}

Land loss is the synergistic culmination of many individual and multiple impacts. These impacts are both natural and human induced. Natural land loss is caused by subsidence and net erosion in abandoned river deltas, whereas land loss caused by humans results from such activities as reclamation and dredging. In this section of the paper we discuss the various causes of land loss and their relative importance.

\section{Natural Land Loss}

Land subsidence. Land subsidence, the lowering of land surface relative to sea level, plays an active role in the coastal zone. The causes of subsidence are (1) regional subsidence caused by base downwarping (isostatic adjustment). from sedimentary loading; (2) compaction of sediments; (3) tectonic activities, including faulting, folding, fracturing, and flowing within the thick sedimentary section; and (4) eustatic sea level changes (Adams and others 1976).

Compaction of sediment is a result of several factors, some of which are caused by humans. These are:

1. Differential consolidation owing to textural variability in the sediments (natural).

2. Consolidation of underlying sediments from the weights of such features as natural levees, beaches, and artificial levees-particularly when the features 
have been deposited over weak compressible foundations (both natural and man-made).

3. Lowering of water table through extraction of ground water, petroleum, salt, or sulfur; also "reclamation" practices that employ diking, construction of watercontrol structures, and drainage of lands for agriculture or urban use (human induced).

The direct supply of sediment from the Mississippi River which has historically balanced the effect of subsidence has been largely eliminated because of levee construction. Some compensatory sedimentation comes from the organic matter deposited on the floor of the marsh and estuary by marsh plants, but it is generally not enough to counteract the subsidence rate.

Delta growth and decay. For the past several thousand years, the Mississippi River has followed a pattern of extending a delta seaward into the Gulf in one area and, after a few hundred years, abandoning it gradually in favor of a shorter adjacent route of steeper gradient (Morgan and Larimore 1957). The modern Birdfoot delta is the latest of seven major lobes of the Mississippi. The abandoned deltas are in various stages of decay (Table 4).

Rates of subsidence and erosion of an abandoned subdelta follow a decelerating pattern. Immediately upon abandonment, interstitial water losses of the sediment are high as are resulting subsidence rates. As connate fluids are lost, the rate of compaction and subsidence gradually diminishes (Morgan and Larimore 1957). Shoreline retreat is highest in young deltas and slowest in older deltas (Table 4).

Loss of barrier islands and inlet widening. Barrier islands, such as Timbalier, Grand Isle, and Grand Terre, are a

Table 4 Deltaic units of Mississippi River shoreline retreat and land loss (Morgan and Larimore 1957)

\begin{tabular}{lccc}
\hline & $\begin{array}{c}{ }^{14} \mathrm{C} \text { age of } \\
\text { deltaic units: } \\
\text { years ago } \\
\text { before present }\end{array}$ & $\begin{array}{c}\text { Shoreline } \\
\text { retreat } \\
(\mathrm{m} / \text { year) }\end{array}$ & $\begin{array}{c}\text { Land } \\
\text { loss } \\
\text { (ha/year) }\end{array}$ \\
\hline $\begin{array}{l}\text { Late Lafourche Subdelta } \\
\text { Early Lafourche }\end{array}$ & $200-300$ & 19 & \\
$\quad$ Subdelta & $800-1500$ & 8.2 & 606 \\
$\begin{array}{l}\text { Barataria Area } \\
\quad \text { Barataria-St. Bernard }\end{array}$ & & & \\
$\quad \begin{array}{l}\text { Subdelta) } \\
\text { St. Bernard Area } \\
\quad \text { Barataria-St. Bernard } \\
\quad \text { Subdelta) }\end{array}$ & $2200-2700$ & 4.9 & 843 \\
$\begin{array}{l}\text { Teche Subdelta } \\
\text { Maringouin Subdelta }\end{array}$ & $2200-2700$ & 4.2 & 676 \\
\hline
\end{tabular}

strong defense against marine processes and hurricanes. The tidal passes associated with barrier islands can be viewed in part as control valves of the estuaries (Gagliano 1973) because they regulate the amount of high-salinity water, storm energy, etc., that enters the estuaries.

The barrier islands along the coast are eroding. In the Barataria hydrologic unit, Grand Isle and Grand Terre have been listed as areas of "critical erosion" by state and federal agencies studying erosion. Between 1960 and 1972 , 71 ha (18\%) of the principal Grand Terre Island was eroded away. Between 1932 and 1969 the average rate of barrier island erosion in the Barataria hydrologic unit was $20.2 \mathrm{ha} /$ year. The rate of increase in the width of the tidal passes in the Barataria Bay area is increasing (Van Sickle and others 1976).

\section{Human-Induced Alterations}

Flood control. The Mississippi River deltas historically have been areas of dynamic change as a result of fluvial processes advancing the delta seaward and marine erosion coupled with subsidence encouraging delta retreat. As a result of many years of levee construction, the Mississippi River has been effectively "walled in." When major floods occur and the carrying capacity of the channel is exceeded, relief outlets through Birds Point-New Madrid (Missouri) and the Atchafalaya and Bonnet Carre (Louisiana) floodways are opened and the flat lowlands at the junction of tributaries with the Mississippi are flooded. These floodcontrol measures have interrupted the balance between riverine and marine processes. Most of the sediment and nutrients of the river are now being deposited in the deep Gulf of Mexico and do not contribute to the construction or maintenance of the coastal wetlands. The development of the Atchafalaya delta is an exception.

Canals. Canals built for oil recovery, navigation, and other activities densely interlace the coastal zone. Natural channels in the marsh are usually not deep enough or well enough located for the requirements of industry. The construction of these canals has led to direct land loss by dredging and spoil deposition and to changes in hydrology.

Many channels began as small pirogue ditches, dug by trappers. However, through repeated use, storms, and current flow, they enlarged and have become major landscape features. They are now permanant. The only indications of human origin lie in their straightness and relationship to the natural waterway. The work of the canal builders continues to have a decisive and cumulative impact on wetlands environment. Some trails (trainasse) are over 100 years old and have become a vital part of the total transporta- 
Table 5 Annual increase of canal width and the time necessary to double the canal area

\begin{tabular}{|c|c|c|c|}
\hline $\begin{array}{c}\text { Example } \\
\text { (years of survey) }\end{array}$ & Source & $\begin{array}{c}\text { Annual } \\
\text { increase of } \\
\text { canal width } \\
\text { (\%/year) }\end{array}$ & $\begin{array}{c}\text { Doubling } \\
\text { time } \\
\text { (years) }\end{array}$ \\
\hline $\begin{array}{c}\text { A. Bayou St. Denis } \\
(1926-1976)\end{array}$ & $\begin{array}{l}\text { Davis } \\
\quad(1973)\end{array}$ & 8.2 & 8.4 \\
\hline $\begin{array}{l}\text { B. Humble Canal } \\
\text { (1953-1958) }\end{array}$ & $\begin{array}{l}\text { Nichols } \\
\quad(1958)\end{array}$ & $\begin{array}{ll}1 . & 8.3 \\
2 . & 7.5 \\
3 . & 6.9 \\
4 . & 6.5\end{array}$ & $\begin{array}{r}8.3 \\
9.3 \\
10.1 \\
10.7\end{array}$ \\
\hline C. Superior Canal & $\begin{array}{l}\text { Nichols } \\
\quad(1958)\end{array}$ & $\begin{array}{ll}1 . & 14.8 \\
2 . & 12.4 \\
\text { 3. } & 13.9 \\
\text { 4. } & 12.4\end{array}$ & $\begin{array}{l}4.7 \\
5.6 \\
5.0 \\
5.6\end{array}$ \\
\hline $\begin{array}{c}\text { D. Golden Meadow } \\
(1940-1953) \\
(1953-1969)\end{array}$ & $\begin{array}{l}\text { This } \\
\text { study }\end{array}$ & $\begin{array}{ll}1 . & 2.0 \\
2 . & 3.7 \\
3 . & 4.0 \\
4 . & 2.0 \\
5 . & 3.0 \\
6 . & 4.6 \\
7 . & 3.0 \\
8 . & 2.0\end{array}$ & $\begin{array}{l}34.6 \\
18.5 \\
17.2 \\
34.6 \\
23.1 \\
15.0 \\
23.1 \\
34.6\end{array}$ \\
\hline $\begin{array}{c}\text { E. Falgout Canal } \\
(1905-1970)\end{array}$ & $\begin{array}{l}\text { Davis } \\
\quad(1973)\end{array}$ & 9. 4.6 & 15.0 \\
\hline
\end{tabular}

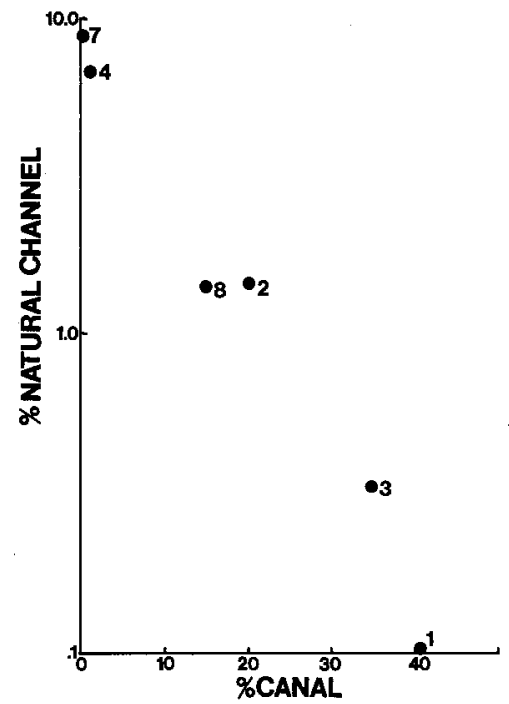

Figure 2. The relationship between canal density and the density of natural channels. The data are averages of replicate $1-\mathrm{km}^{2}$ grids (number shown by symbol) in the region of Leeville, La., a saline marsh area. tion network; they are a.visible segment on the landscape and have affected drainage patterns, influenced salinities, and are a reminder of man's abilities to unknowingly change the delicate balance in the natural system. (Davis 1973)

Numerous examples demonstrate the widening of various canals over extended periods of time. Canals widen through usage, generally as a result of wave action and altered hydrologic patterns. Another important factor is the condition of the marsh substrate; the softer or more fluid and organic the marsh, the more susceptible it is to erosion.

It is evident from the few examples available that canal widening is occurring throughout the entire coastal zone, influencing the geologically more stable chenier plan as well as the deltaic plain (see Fig. 1). Its influence also transcends the various marsh types, affecting fresh, brackish, and saline marsh. The annual increase in canal width ranges from about 2 to $14 \%$ per year for a doubling time of 5-60 years (Table 5). The area of canals increases as the area of natural channels decreases (Fig. 2), reflecting a change in hydrology as canals are built. We shall attempt to put this in perspective. Gagliano and van Beek (1970) estimated that 4,345 ha or $<0.3 \%$ of coastal Louisiana's land is being lost each year because of all factors - natural and human induced. Canals, which represent $2-4 \%$ of this total (now), are widening at a rate an order of magnitude greater than the present land loss rate and may eventually be the dominant factor causing land loss in Louisiana-simply by widening at the current rate. For example, assume an enlargement rate of $5 \%$ per year. This is equivalent to a doubling rate of 14 years. In 14 years, therefore, the present $2.6 \%$ canal density in Barataria Bay (Table 1) may become $5.2 \%$ of the total area, or $\sim 10.0 \%$ by the year $2001,20 \%$ by 2020.

These figures are preliminary estimates but the analysis indicates that further work is warranted on this subject. Either boat traffic or increased water flow in the canals is likely to contribute to canal widening. Plugging canals at both ends and at intervals between is often done and should reduce the water flow and eliminate boat traffic, thus decreasing the annual rate of widening.

Spoil banks. The discussion to this point has been concerned with only the surface area of wetland loss caused by dredging. This, however, ignores the area of spoil banks created in the process. Spoil, the material excavated by dredging, is most often deposited alongside the dredged area and results in additional loss of wetland. Revegetation of the spoil area eventually does occur but the change in elevation causes a change in species composition. At elevations above high water, a canopy of shrubs and small trees 
develops (Monte 1975). It is also possible that marshes near the spoil banks deteriorate because of impact of the bank on the surrounding marsh. A specific example is the Mississippi River Gulf Outlet (MRGO), a direct navigation canal from New Orleans to the Gulf of Mexico. Construction of the MRGO resulted in the destruction of 9,714 ha of marsh comprised of 2,695 ha for the channel and 7,019 ha for spoil deposition (Rounsefell 1964). The ratio of canal area to spoil area is $1: 2.6$. McGinnis and others (1972) noted that for a $15 \mathrm{~m}$-wide pipeline flotation canal the direct conversion of marsh area to canal area was $1.53 \mathrm{ha} / \mathrm{km}$. The conversion of marsh to spoil levee was $5 \mathrm{ha} / \mathrm{km}$ (canal : spoil ratio of $1: 2$ to $1: 3$ ). They noted that the total marsh area with altered character would be about $10 \mathrm{ha} /$ $\mathrm{km}$. Nichols (1958) suggests that the area of land with altered productivity is five to six times that of the canal itself.

The inclusion of spoil bank area in the total figures for wetland loss indicates that canals may be much more important in land loss than previously indicated. For example, Gagliano and van Beek (1970) estimated that of the total land loss of $4,345 \mathrm{ha} /$ year, $39 \%$ was due to canals. However, if a ratio of canal area to spoil area of $1: 2.5$ is used (as indicated by the above references), then canals are responsible for $69 \%$ of total land loss.

During the period 1931-1967 covered by Gagliano's and van Beek's study (1970), therefore, wetland losses may have been higher than they estimated. Adams and others (1976) estimate that $2.6 \%$ of the wetland area in the Barataria hydrologic unit has been converted to canals. Using the above ratios, the total wetland area lost because of canals may be nearly $10 \%$, if spoil area is included. The area of wetland affected by canals in the Barataria hydrologic unit may approach $20 \%$ of the total wetland area if the area of wetland affected by canals is five to six times the area of the canal (McGinnis and others 1972, Nichols 1958). This suggests that the effects of canals may be much greater than formerly thought. We believe that more study is needed on both the ratio of canal area to spoil area and the indirect effects of canals.

Land reclamation. Land reclamation programs have been attempted in Louisiana since the early eighteenth century. These drainage projects, mainly for agricultural purposes, reached a peak between 1915 and 1920 . The majority of these failed because of poor drainage, deterioration of levees, seepage, and the shrinkage and oxidation of the organic soils-all resulting in land loss. The marshes of the coastal zone have numerous rectangular lakes that document the failures of these projects (e.g., Shlemon 1972).

Land reclamation of the wetlands for urban and industrial developments began in earnest by 1910 . New Orleans is the most extreme example of this expansion. By the late ninteenth century New Orleans had used all the available high natural levee land and began expanding into the marshes and swamps. This expansion continues today. "Active and proposed schemes related to industrial sites, nuclear power plant locations, planned communities, recreation complexes (harbor towns and fishing resorts), airports, and Florida-type waterfront communities are appearing at an alarming rate" (Gagliano 1973). Although this is not direct land loss, it is direct marsh loss and results in loss of habitat, waste buffer, storm barrier, and nursery grounds.

Substrate. The types of land loss discussed above are all locally affected by the substrate type, i.e., clay, silt, peaty areas, natural levees, or beaches. Across the coastal zone, particularly in the deltaic plain, the substrate is highly diverse and in many cases unstable, resulting in a complex, variable surface (Adams and others 1976). A three-dimensional knowledge of an area can help explain local variations in land-loss rates. A network of natural levees, at the surface or submerged, provide a more solid, stable substrate than the surrounding marsh. Such areas are capable of withstanding erosional forces, such as wave attack, for longer periods of time. Organic soils, such as muck (20-50\% organic content) and peat ( $75 \%$ organic content), are more unstable and more susceptible to the natural and manmade forces influencing land loss.

\section{Human-Induced versus Natural Land Loss}

If land loss in the coastal zone were caused largely by natural processes; the oldest deltas might be expected to be losing land at the slowest rate, whereas the youngest would be losing land at the fastest. Although this is true for shoreline retreat (Morgan and Larimore 1957; Table 4), it does not seem true for land loss in the four comparable areas with available data.

Price (1947) noted that the different forces involved in the geometry of coastal basins tended to result in some predictable relationships between basin width and depth. Modification of (basin form) is most evident after great storms or major engineering works; basin segmentation, channeling, and canal construction seemed to be principle causal agents for some changes he observed in the morphology of many of the larger basins along the Gulf of Mexico coastline.

We therefore decided to investigate the relationship between land losses in the coastal zone and canal density. Canal density is a rough approximation of one type of marsh management and canals are the dominant form of human alterations of the Barataria Bay estuary. The composite map used for Table 3 was digitized to estimate land losses 
in each of the nine coastal hydrologic units. These were compared to canal density measured by Chabreck (1972). Second, Adams' and others' (1976) data for land loss in Barataria Bay (1970-1974) were also summarized. The results are in Table 6. Land loss is directly proportional to canal density for each example. Notice that the intercept of the regression equation for the data is similar (0.10 vs. $0.074 \%$ land loss per year) and that land-loss rates are several times higher than that caused by canal density. We believe that this intercept is probably as good an estimate as we can now generate of the actual land losses caused by changes in land elevation relative to sea level. Canals appear to promote land loss in a predictable manner.

Summarizing, canals result in direct loss of habitat through dredging and spoil disposal and an indirect landloss effect resulting from changes in hydrology, saltwater intrusion, and acceleration of marsh deterioration.

\section{Summary}

The coastal zone is the result of a balance between marine and riverine influences. Land building is caused by sediment deposition from delta progradation and overbank flooding and, to an extent, by compensatory sedimentation

Table 6 The relationship of land loss in the coastal zone (\% marsh per year) and human activities as estimated by canal density ( $\%$ total marsh) area

\begin{tabular}{lcclc}
\hline A. For each hydrologic units (7) in the coastal zone \\
\hline Activity & n & Range & $\begin{array}{c}\text { Canal } \\
\text { density (x) } \\
\text { mean (S.D.) }\end{array}$ & $\begin{array}{c}\text { Land } \\
\text { loss (y) } \\
\text { mean (S.D.) }\end{array}$ \\
\hline $\begin{array}{l}\text { Light } \\
\text { Moderate }\end{array}$ & 1 & $0 \leq 1$ & $1.0(-)$ & $0.12(-)$ \\
Heavy & 4 & $>1 \leq 3$ & $1.64(0.41)$ & $0.30(0.16)$ \\
& 2 & $>3$ & $9.6(7.9)$ & $0.86(0.33)$
\end{tabular}

Equation of best fit: $y=0.10+0.079(x) ; R^{2}=0.97$

B. For several selected areas in Barataria Bay

\begin{tabular}{|c|c|c|c|c|}
\hline Activity $^{c}$ & $\mathrm{n}$ & Range & $\begin{array}{c}\text { Canal } \\
\text { density }(x)^{\mathrm{c}} \\
\text { mean (S.D.) }\end{array}$ & $\begin{array}{c}\text { Land } \\
\text { loss }(\mathrm{y})^{\mathrm{c}} \\
\text { mean (S.D.) }\end{array}$ \\
\hline Light & 3 & $0 \geq 1$ & $0.34(0.35)$ & $0.007(0.024)$ \\
\hline $\begin{array}{l}\text { Light- } \\
\text { moderate }\end{array}$ & 2 & $>1 \leq 2$ & $1.31(0.11)$ & $0.093(0.071)$ \\
\hline Moderate & 1 & $\geq 2<3$ & $2.0(-)$ & $0.084(-)$ \\
\hline Heavy & 1 & $>3$ & $2.81(-)$ & $0.105(\rightarrow)$ \\
\hline
\end{tabular}

Equation of best fit: $y=0.074+0.01(x) ; R^{2}=0.69$

${ }^{a}$ Chabreck (1972).

b This study.

c Adams and others (1976). from organic matter deposited by marsh plants. The rate of this land building is modified by water flow, type of sediment, water depth, and vegetation.

Flood control measures and navigation projects have interrupted the natural balance between riverine and marine processes which built and stabilized the marsh areas.

Other factors influencing land loss are the following:

1. Subsidence

2. Loss of barrier islands and inlet widening

3. Type of substrate

4. Lass of sediment input

5. Shoreline retreat

6. Salinity changes

7. Canals and spoil areas

8. Land reclamation projects, impoundments

9. Hurricanes, marsh fires, overgrazing by muskrats and nutria

10. Erosive forces-currents, wave energy, etc.

These factors, both natural and man-made, interact in a complex manner. For example, the loss of sediment input increases the rate of loss of barrier islands and inlet widening. This in turn increases the rate of salinity intrusions and erosion.

The implication of our analysis is that canal construction has a long-term impact beyond the actual loss of land used for the canal itself. In addition, the area of spoil and levees created in the building process and maintenance is at least 1:2 for canal to spoil, and often higher. An estimated 10\% of the wetlands in Barataria Bay (the only area with a strong data base) has been lost as a direct result of canal construction activities.

We have summarized some of these results in Table 7 . Selected areas of the coastal zone have historically accumulated land at about $0.3 \mathrm{~km}^{2} /$ year. This net gain has been maintained against an apparent gross loss rate of about 2.2 $\mathrm{km}^{2}$ /year. Yet recently, since both major control efforts of the Mississippi River and alteration of the coastal wetlands began in this century, there has been a net loss of land. We find it difficult to interpret the data in any other way but to say that both (1) attempted control of river flooding and subsequent rediversion of sediments and (2) alteration of wetlands, and canals in particular, are the dominant factors causing the observed recently increased rates of land loss in Louisiana's coastal zone. There is every indication that these losses will continue, perhaps accelerate, as a legacy with which this generation and future generations must contend.

\section{Cumulative Impacts of Land Loss}

Some of the cumulative impacts of land loss are changes in the hydrology of the various systems resulting in saltwa- 
ter intrusion and eutrophication, loss of an important storm buffer, loss of the waste treatment afforded by healthy marsh, direct loss of habitat, and loss of nursery grounds of commercially important fish and shellfish.

\section{Salinity Changes and Eutrophication}

As previously mentioned, there are trends of increasing salinity in much of the coastal zone (Van Sickle and others 1976, Gagliano and others 1970b). Increasing salinity is a cause of land loss, and land loss in turn may result in increasing salinity. As the saline marsh deteriorates, the hydrology of the system changes and salt water may extend into the brackish marsh, causing more land loss and creating a positive feedback loop with no control. This is coupled with a reduction of freshwater input and sediments from the Mississippi River which could increase the effect of saltwater intrusion.

\section{Waste Buffer}

Canals short-circuit the natural flow of nutrient-laden water into lakes and bays instead of allowing it to trickle through the wetlands. This flow of water from urban runoff, agriculture, and sewage goes directly into water bodies via canals, causing hypereutrophic conditions in the lakes and bays. A study done by Craig and others (1977) in Barataria Basin indicates that if present rates of development, which lead to increased eutrophication, and salinity intrusions continue, there is the potential for the degradation of the nursery grounds of the commercial fisheries associated with Barataria Basin.

The eutrophic conditions created by shunting nutrientladen water into lakes and bays can be mitigated by allowing the water to trickle through the basin where the nutrients are taken up by wetland soils and vegetation. Marshes have evolved adaptations to high nutrient levels and can remove and recycle inorganic nutrients (tertiary treatment; Axelrad 1974, Heinle and Flemer 1976, Grant and Patrick 1970) at a much cheaper cost than if done artificially by humans. In Barataria Basin, this "free work" of nature could be equivalent to $\$ 5.6-23.6$ million per year if overland flow waste treatment were used rather than tertiary treatment. This would also serve to increase marsh productivity (Craig and others 1977). Loss of marsh is loss of this important waste buffer. A hectare of marsh-estuary (calculated from mid-Atlantic estuaries) is capable of doing about $\$ 1.4,000$ worth of tertiary treatment (inorganic nutrient removal) per year at a daily loading of nutrients equivalent to $8.8 \mathrm{~kg} \mathrm{BOD}$, assuming the cost of artificial treatment is $\$ 1.6 / \mathrm{kg}$ BOD. In other words, this is what it would cost to artificially treat this waste, if wetland were not available to do this work (Gosselink and others 1974).
Table 7 Historical land gains ( + ) and losses ( - ) in the Louisiana coastal zone

\begin{tabular}{|c|c|c|}
\hline Area & $\mathrm{km}^{2} /$ year & Source \\
\hline \multicolumn{3}{|l|}{$\begin{array}{l}\text { A. Mississippi Delta growth rates } \\
\text { (duration, year) }\end{array}$} \\
\hline West Bay $(90)$ & +0.39 & Schlemon (1972) \\
\hline Baptiste Collete (50) & +0.077 & Schlemon (1972) \\
\hline Cubits Gap (75) & +0.36 & Schlemon (1972) \\
\hline Garden Island Bay (40) & +0.29 & Schlemon (1972) \\
\hline Average & +0.28 & \\
\hline Atchafalaya Delta & & \\
\hline $\begin{array}{l}\text { (1970-2020; } \\
\text { growth phase) }\end{array}$ & +2.15 & Schlemon (1972) \\
\hline \multicolumn{3}{|l|}{ B. Coastal Louisiana } \\
\hline Net historical gain & & Chabreck (1972), \\
\hline (5030 B.C. -1970 A.D.) & +0.32 & Frazier (1967) \\
\hline Recent net loss $(1890-1960)$ & -6.37 & $\begin{array}{l}\text { Gagliano and van } \\
\text { Beek (1970) }\end{array}$ \\
\hline $\begin{array}{l}\text { Recent "natural" loss caused } \\
\text { by subsidence and erosion } \\
(1890-1970)\end{array}$ & -2.22 & $\begin{array}{l}\text { Calculated } \\
\text { at } 0.10 \% / \text { year } \\
{\text { (Table } 6)^{\mathrm{a}}}^{\text {(T) }}\end{array}$ \\
\hline $\begin{array}{l}\text { Recent losses attributable } \\
\text { to human activities } \\
\text { excluding the effects of } \\
\text { Mississippi River water } \\
\text { control engineering } \\
\text { (recent minus recent }\end{array}$ & & \\
\hline $\begin{array}{l}\text { natural losses) } \\
\text { Including the effects of }\end{array}$ & -4.15 & $(-6.37)-(-2.22)$ \\
\hline $\begin{array}{l}\text { Mississippi River water } \\
\text { control engineering } \\
\text { (historical plus recent) }^{\mathbf{b}}\end{array}$ & -6.69 & $0.32+(-6.37)$ \\
\hline & & \\
\hline
\end{tabular}

a If the Mississippi River were leveed and no activity had taken place in wetlands (e.g., canals) then there would have been a certain "natural" loss rate not compensated for by land gain. We calculated this to be $2.22 \mathrm{~km}^{2}$ year from the $y$ intercept in Table 6 . The difference between this natural loss rate and total recent net loss $\left(6.37 \mathrm{~km}^{2} /\right.$ year $)$ can be attributed to human activities.

bince leveeing of the river is part of man's work, then the total land loss which can be attributed to humans is the recent net loss plus the net historical gain.

\section{Storm Buffer}

The salt marsh is an important hurricane buffer, absorbing the energy of storm waves and providing a water reservoir for storm waters. "Some idea of the protective value of a wide band of energy-absorbing marshes and barrier islands is seen in the increasing national cost for 'disaster relief' in coastal areas which either lack these natural protective 'breakwaters' or where they have been filled in or bulkheaded for housing or other development" (Gosselink and others 1974). Marsh- and island-protected coasts suffer comparatively little damage even in fierce hurricanes. Without marshes storm damage would be much higher than it is. 


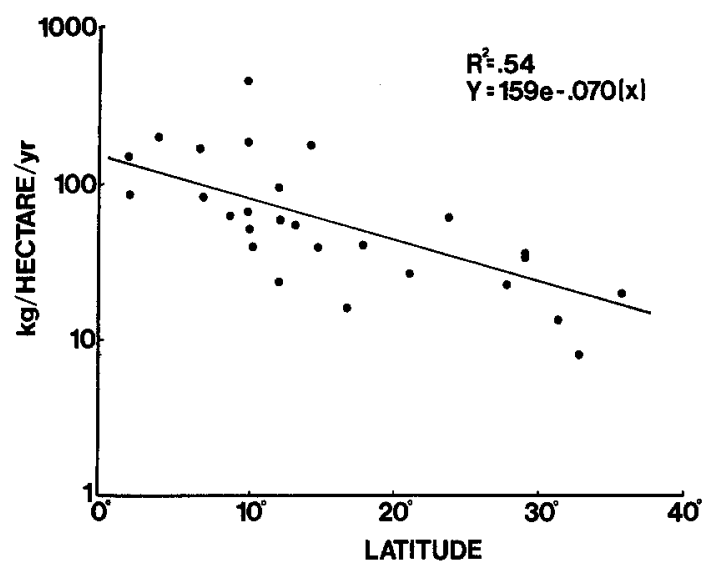

Figure 3. The relationship between average annual yield of shrimp per area of wetland $(\mathrm{kg} / \mathrm{ha})$ and latitude (adapted from Turner 1977).

\section{Fisheries}

The impact of land loss on commercial fisheries yields is directly related to the area of coastal wetlands lost. One example of this coupling between wetlands and fisheries yields in the coastal zone is the direct relationship between offshore shrimp yields and wetland area on a worldwide basis (Fig. 3). The yield of shrimp per hectare of wetland area is higher toward the equator but the relationship follows a consistent pattern in spite of the inaccuracies inherent in the data. The relationship between intertidal areas and inshore yields of shrimp in Louisiana are shown in Fig 4. Higher yields are associated with larger areas of wetlands and only incidentally with water surface area or volume. Neither of these data sets includes any adjustments to compensate for movements of the fishing craft or the organisms from nursery grounds to where they are harvested or landed. Therefore, the official data may not record that Alabama vessels may harvest Louisiana's menhaden in Mississippi waters.

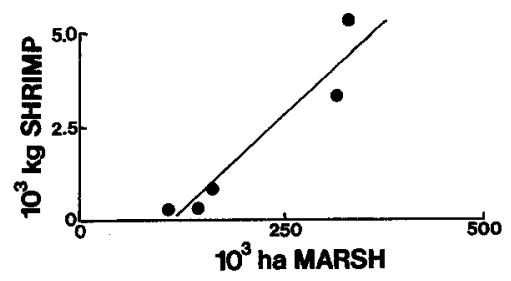

Figure 4. The relationship between the average annual yield of shrimp behind barrier islands (inshore area) and the area of marshland in that hydrologic unit (adapted from Turner 1977).
In light of these relationships, in the absence of conflicting data, and with knowledge of the fisheries value of estuaries in the Gulf of Mexico (e.g., McHugh 1966), we can directly correlate wetland losses with fisheries losses. To do this we need to estimate the yields and value of Louisiana's fisheries. The recent rise in Louisiana landings is because of the opening of several menhaden (Brevoortia sp.) processing plants in south Louisiana. Reported shrimp landings have remained essentially constant since the 1950 s in spite of a much larger fishing fleet, changes in techniques, and rising prices. The very large variations in annual yields may mask the impact of land losses (6-10\% for 10 years). We will use here the average yield for $1969-1973$ of $554 \times 10^{6} \mathrm{~kg}$. In the future other species may be exploited, but presently the catch per unit effort for both shrimp and menhaden has peaked or begun to decrease. These two species represent a major portion of the landings weight and value to fisheries industry. Shrimp generally represent $60-70 \%$ of the total dockside or exvessel value of all fisheries landings value (the exvessel value is generally $60 \%$ of the processed value). The price per pound of product has almost doubled in the last 10 years, so the latest data (1973) have been used to compute the exvessel value to Louisiana $(14.8 \mathrm{c} / \mathrm{kg})$. This price does not include the social, esthetic, recreational, or other values of marshes (e.g., Gosselink and others 1974). The total average annual value of Louisiana fisheries based on 1973 prices and $1969-1973$ landings is thus $\$ 82$ million, exvessel ( $\$ 137$ million, processed). The direct loss of marshlands from spoil banks and canals is at least $2.6-5.2 \%$ (Table 1 and previous discussion) of the total area. This percentage would be higher, of course, if land erosion were assumed to be partially a result of canal construction, as suggested in the previous figures and discussion. Using this wetland loss, a minimum estimate is $\$ 2.1-4.3$ million annually "lost" as a cumulative consequence of previous canal construction (or $\$ 3.6-7.1$ million based on the processed value). This value will change as more canals are built, as previously built canals widen and/or cause further erosion, and as the economic structure of the industry changes or other geologic factors predominate. Additionally, for each dollar spent on fisheries directly, approximately $\$ 3$ are spent indirectly (Jones and others 1974). In general economic terms, this multiplier effect means that the present cumulative economic (fisheries only) impact of land loss is a minimum of $\$ 8.5-17.1$ million annually.

\section{Management Concepts and Guideline Recommendations}

There are two means of minimizing land losses: Additional land can be built (1) to offset the loss of land in other 
areas, and (2) to reduce, where possible, the impact of those natural and man-made factors which are most important in increasing land losses.

Land building could be accomplished in several different ways. Gagliano and others (1970a) outlined a program to create man-made diversions of the Mississippi River in order to initiate new subdelta lobes, increase upper deltaic plain aggradation, and control salinity patterns. In their view, the most efficient way to build land is simply to create diversions into broad, shállow lakes and sheltered bays. To increase biologic productivity, however, it may be more useful if additional subdelta lobes extended beyond the existing Gulf shoreline. At present, there are many legal problems associated with this, but if land losses in the coastal zone become critical, innovative techniques such as this will need to be employed.

Another method of land building is to develop creative means for spoil disposal in efforts to convert the spoil into viable marsh areas.

Land building, currently, is in progress in the Atchafalaya Delta and could be optimized by proper management techniques.

To prevent or minimize the amount and rate of land loss due to human activities (and to insure the continuation of Louisiana's productive wetland resources), we have formulated the following guidelines based on this study and the work of others. These center on avoiding the disruption of wetland hydrology. Some recommendations have legal status in some states; other guidelines are inconsistently followed or ignored.

1. Construct no new canals that connect (a) the edge and center of a hydrologic basin and (b) fresh and saltwater areas.

2. Plug pipeline canals wherever possible at both ends and at intervals between in order to reduce water fow and eliminate boat traffic and to decrease the annual rate of widening. If a canal crosses a natural creek bank, plugs should be placed where the canal intersects the natural tributary.

3. Build no new wetland impoundments.

4. Minimize new canal construction by multiple use of existing canals, integrated planning, common use of pipeline canals, directional drilling, etc. The alignment of canals should take advantage of the existing natural or man-made channels.

5. Reserve adequate spoil disposal sites and easements on high, dry land (nonwetland areas) for future dredging; or use the spoil to build "new" marsh.

6. Avoid "fingerfill" development in wetlands by restricting residential development and canals to nonwetland areas.

\section{Management Data Needs}

On the basis of the information reviewed in this paper, our experiences with the biology of Louisiana's marshes, and our understanding of coastal zone management needs, we feel that the following data should be developed in order to more fully comprehend the magnitude and implication of land loss:

1. Canals apparently are an important factor in land loss. This needs to be investigated more thoroughly. Especially important is the further documentation of:

a. Canal density and land loss in relationship to different substrate, vegetation, and hydrologic regimes.

b. Canal widening vs. width over long period of time.

c. Wetland losses as a consequence of different spoil disposal practices.

2. The couplings of sediment sources, sinks, and hydrology need to be further explored in order to develop a clearer perspective of the consequences of man-made changes in hydrology, especially the cumulative impacts.

a. What is the impact of "channel" widening and deepening at barrier island inlets on the hydrology of an entire hydrologic unit? Obvious case studies in Louisiana are the Calcasieu ship channel, the Mississippi River Gulf Outlet near New Orleans, and the Barataria Bay Waterway.

b. How will different schemes for "controlled diversions" of sediment-rich water affect entire basins?

3. Planning for management of the newly emerging Atchafalaya Delta should begin in toto now. This is new land owned entirely by the people of the state of Louisiana. A piecemeal management approach for the temporary benefit of a few interest groups is in the long run unsatisfactory. A long-term planning perspective is necessary to optimize its potential benefits-economic, social, environmental, recreational, cultural, and others.

4. The couplings within wetlands need to be more fully appreciated. No project should be approved without considering its impact on the entire hydrologic units. In particular:

a. Public agencies need a clear documentation of these couplings.

b. The natural work services of wetlands should be considered in evaluating project impacts-especially the long-term impacts on biologic productivity and what is known as "secondary impacts" that accompany successful project development. An outline of these probable secondary developments is needed for a more complete basis for planning. 


\section{Acknowledgements}

We thank R. D. Adams, J. G. Gosselink, W. H. Patrick Jr., P. Templet, and colleagues in the Coastal Ecology Laboratory, Center for Wetland Resources, Louisiana State University. We thank $\mathbf{K}$. Higgins for the raw data used in Figure 2. This work was supported by the Louisiana State Planning Office and the Louisiana Sea Grant Program, a part of the National Sea Grant Program maintained by the National Oceanic and Atmospheric Administration, United States Department of Commerce. The United States Government is authorized to produce and distribute reprints for governmental purposes notwithstanding any copyright notation that may appear hereon.

\section{Literature Cited}

Adams, R. D., B. B. Barrett, J. H. Blackmon, B. W. Gane, and W. G. Mcintire. 1976. Barataria Basin: Geologic processes and framework. Louisiana State University, Center for Wetland Resources, Baton Rouge, La. Sea Grant Publ. No. LSU-T-76-006.

Axelrad, D. M. 1974. Nutrient flux through the salt marsh ecosystem. Ph.D. dissertation, College of William and Mary. Virginia. $133 \mathrm{pp}$.

Barrett, B. 1970. Water measurements of coastal Louisiana. La. Wildlife and Fisheries Commission, U.S. Dept. of Interior Fish and Wildlife Service, Bureau of Commerce Fisheries Proj. 2-22T, P.L. 88-309.

Chabreck, R. 1972. Vegetation, water, and soil characteristics of the Louisiana coastal region. La. Agriculture Experimental Station, AEA Information Series No. 25.

Chabreck, R., T. Joanen, and A. W. Palmisano. 1968. Vegetative type map of the Louisiana coastal marshes. La. Wildlife and Fisheries Commission, New Orleans, La.

Cook, E. F. 1978. Progress or prudence? Louisiana State University Center for Wetland Resources, Baton Rouge, La. 4th Annual Marine Sciences Distinguished Lecture. 25 pp.

Craig, N. J., J. W. Day Jr., P. Kemp, A. Seaton and W. G. Smith. 1977. Cumulative impact studies in the Louisiana coastal zone: Eutrophication. Rept. to Louisiana State Planning Office, 92 pp.

Davis, D. W. 1973. Louisiana canals and their influence on wetland development. Ph.D. dissertation, Louisiana State Univ., Baton Rouge.

Frazier, D. D. 1967. Recent deltaic deposits of the Mississippi: Their development and chronology. Trans. Gulf Coast Assoc. Geol. Soc. 17:287-315.

Gagliano, S. M. 1973. Canals, dredging, and land reclamation in the Louisiana coastal zone. Hydrologic and Geologic Studies of Coastal Louisiana, Rept. No. 14. Coastal Resources Unit, Center for Wetland Resources, Louisiana State Univ., Baton Rouge.

Gagliano, S. M., and J. L. van Beek. 1970. Geologic and geomorphic aspects of deltaic processes, Mississippi Delta system. Hydrologic and Geologic Studies of Coastal Louisiana, Rept. No. 1. Coastal Resources Unit, Center for Wetland Resources, Louisiana State Univ., Baton Rouge.
Gagliano, S. M., H. J. Kwon, and J. L. van Beek. 1970a. Deterioration and restoration of coastal wetlands. Proc. 12th Coastal Engr. Conf. 3:1767-1781.

Gagliano, S. M., H. J. Kwon, and J. L. van Beek. 1970b. Salinity regimes in Louisiana estuaries. Hydrologic and Geologic Studies of Coastal Louisiana, Rept. No. 2. Coastal Resources Unit, Center for Wetland Resources, Louisiana State Univ., Baton Rouge.

Gosselink, J. G., and R. H. Baumann. 1978. Wetland Inventories: Wetland loss along the United States' coast. Proceedings of the Association of American Geographers and International Geographers Union Symposium on Coastal Environments, New Orleans, La. In Press.

Gosselink, J. G., E. P. Odum, and R. M. Pope. 1974. The value of the tidal marsh. Louisiana State Univ. Center for Wetland Resources, Baton Rouge, La. Sea Grant Publ. No. LSU-SG-74-03.

Grant, R. R., and R. Patrick. 1970. Tinicum marsh as a water purifier in two studies of tinicum marsh. The Conservation Foundation, Washington, D.C.

Heinle, D. R., and D. A. Flemer. 1976. Flows of materials from poorly flooded tidal marshes and an estuary. Mar. Biol. 35(4):359-373.

McGinnis, J. T., R. A. Ewing, C. A. Willingham, S. E. Rogers, D. H. Douglass, and D. L. Morrison. 1972. Environmental aspects of gas pipeline operation in the Louisiana coastal marshes. Final report to Battelle Columbus Labs. Unpublished.

McHugh, J. L. 1966. Management of estuarine fishes. Am. Fish. Soc. Spec. Publ. 3:133-154.

Monte, J. A. 1975. Man-induced vegetation change in the Bayou Lafourche basin, La.: Vegetational success on spoil banks. Ph.D. dissertation, Louisiana State Univ., Baton Rouge.

Morgan, J. P., and P. B. Larimore. 1957. Changes in the Louisiana shoreline. Trans. Gulf Coast Assoc. Geol. Soc. 7:303-310.

Nichols, L. G. 1958. Erosion of canal banks on the Rockefeller Wildlife Refuge. La. Wildlife and Fisheries Commission, Refuge Div., New Orleans, La. (unpublished report).

Price, W. A. 1947. Equilibrium of form and forces in tidal basins of coasts of Texas and Louisiana. Bull. Am. Assoc. Petrol. Geol. 31:1619-1663.

Rounsefell, G. A. 1964. Preconstruction study of the fisheries of the estuarine areas traversed by Mississippi River-Gulf Outlet project. U.S. Fish and Wildlife Service Fisheries Bull. 63(2):373-393.

Shlemon, R. J. 1972. Development of the Atchafalaya Delta. Hydrologic and Geologic Studies of Coastal Louisiana, Rept. No. 13. Coastal Resources Unit, Louisiana State Univ. Center for Wetland Resources, Baton Rouge.

Turner, R. E. 1977. Intertidal vegetation and commercial yields of penaeid shrimp. Trans. Am. Fish. Soc. 106:411-416.

Turner, R. E., and J. G. Gosselink. 1975. A note on standing crops of Spartina altemiflora in Texas and Florida. Contr. Mar. Sci. 19:113-118.

Van Sickle, V. R., B. B. Barrett, and T. B. Ford. 1976. Barataria Basin: Salinity changes and oyster distribution. Louisiana State Univ. Center for Wetland Resources, Baton Rouge. Sea Grant Publ. No. LSU-T-76-002.

Viosca, P. 1928. Louisiana wetlands and the value of their wildlife and fishery resources. Ecology 9:216-229. 